\title{
Papiamentu and the Brazilian Connection Established through the Sephardic Jews ${ }^{1}$
}

\section{(Papiamento y la conexión brasileña establecida mediante los judíos sefardíes)}

\author{
Marco A. Schaumloeffe/2
}

The University of the West Indies, Barbados

\begin{abstract}
This study examines the linguistic contact between Papiamentu and Brazilian Portuguese established when the Sephardic Jews were expelled from Dutch Brazil and some of them relocated in Curaçao. Three lexical items of PA (yaya, 'nanny, nursemaid'; bacoba, 'banana'; and fulabola 'forefinger, index finger') are analysed and put into their historical context to show that their presence in Papiamentu can be attributed to the contact between Brazil and Curaçao due to the forced migration of the Sephardic Jews and their servants.

\section{RESUMEN}

El estudio examina el contacto lingüístico entre el papiamento y el portugués brasileño, establecido cuando los judíos sefardíes fueron expulsados del Brasil Holandés y algunos se trasladaron a la isla Curazao. Tres unidades lexicales del papiamento (yaya, 'niñera, niñera'; bacoba, 'banana'; y fulabola, 'dedo índice) se analizan y ponen en su contexto histórico para mostrar que su presencia en papiamento es atribuible al
\end{abstract}

1 Recibido: 28 de enero de 2019; aceptado: 23 de julio de 2019. An earlier version of this study was presented at the 22nd Biennial Conference of The Society for Caribbean Linguistics (SCL), Heredia/Limón, Costa Rica. 5-12 August 2018.

2 Cave Hill Campus, Faculty of Humanities and Education, Department of Language, Linguistics and Literature. Lecturer in Brazilian Studies. Correo electrónico: marco.schaumloeffel@cavehill. uwi.edu 
contacto entre Brasil y Curazao, con la forzada migración de los judíos sefardíes y sus criados.

Keywords: Papiamentu, Brazilian Portuguese, origins of Papiamentu, Sephardic Jew

Palabras clave: papiamento, portugués brasileño, orígenes del papiamento, judíos sefardíes

\section{Introduction}

Papiamentu (PA) is a creole language spoken mainly in the ABC-Islands, and also in some other islands in the Caribbean and in the Netherlands. ${ }^{3}$ The studies conducted first by Martinus, and later Jacobs, indicate that PA is an Afro-Portuguese-based creole, and more specifically, that it is genetically related to Upper Guinea Portuguese Creole. ${ }^{4}$ There also is a direct historical connection between Curaçao and Brazil, established due to the resettlement of Sephardic Jews, their assistants, and their free and enslaved African and Afro-Brazilian servants from Dutch Brazil to the Caribbean after the Dutch were expelled by the Portuguese from the Northeast of Brazil. Portuguesespeaking Jews from Brazil began to arrive in Curaçao in 1659. This period coincides with the period between 1634 and 1677, considered crucial for the formation of Papiamentu. ${ }^{5}$ Portuguese (PT) was one of the languages spoken by the Sephardic people in Curaçao. From the beginning, the Jewish congregation in Curaçao even used Portuguese for

3 Aruba, Bonaire and Curaçao form the so-called ABC Islands, where Papiamentu is the native language of the majority of the population and is spoken by some 270,000 people. Smaller communities of Papiamentu speakers can also be found in the Netherlands and in the other Caribbean islands of the former Netherlands Antilles (Saba, Sint Eustatius and Sint Maarten). An official language in Aruba and Curaçao, Papiamentu is recognised by the Dutch government in Bonaire. Cf. Silvia Kouwenberg, "Papiamentu Structure Dataset," Atlas of Pidgin and Creole Language Structures Online (Leipzig: Max Planck Institute for Evolutionary Anthropology), 29 January 2017, <http://apics-online.info/contributions/47>.

4 For details, see Frank Martinus, The Kiss of a Slave: Papiamentu's West-African Connections (Amsterdam: Universiteit van Amsterdam, 2004); and Bart Jacobs, Origins of a Creole: The History of Papiamentu and its African Ties (Berlin: De Gruyter, 2012).

5 Bart Jacobs, "The Upper Guinea Origins of Papiamentu Linguistic and Historical Evidence," Diachronica 26, 3 (2009): 353. DOI: https://doi.org/10.1075/dia.26.3.02jac. 
their religious services; they only changed to Spanish in the nineteenth century. ${ }^{6}$ The historical facts involving the dislocation of people from Pernambuco, Brazil to Curaçao naturally led to the assumption of a possible influence of these Portuguese-speaking Sephardic Jews and their Afro-Brazilian servants in the formation of PA.

Although the current body of research on PA completely discards the hypothesis of a Brazilian origin of Papiamentu, as postulated in 1987 by Goodman, ${ }^{7}$ the intention of this paper is to show that links exist between these two areas and that there probably was some secondary degree of influence from Brazilian Portuguese during the formation process of PA. Even if they existed, it certainly would be difficult to prove that some of the PA features present in the deeper layers of the language (i.e., in elements like relators and function words) could be specifically attributed to an influence from Brazilian Portuguese or the Portuguese spoken by the Sephardi, just as it probably would be difficult to clearly set them apart from the features incorporated into PA that are also present in other Portuguese variants and in West African Portuguese-based creoles. However, specific lexical items discussed here show that their transfer to PA may have occurred because of the dislocation of Sephardic Jews and their servants from Brazil to Curaçao. Traces of at least one of those lexical items can also be found in French Guiana and in Suriname, the final destination for some of those expelled from Brazil or the temporary destination as place of passage for others that later headed for Curaçao. The lexical items of PA yaya 'nanny, nursemaid', bacoba 'banana' and fulabola 'forefinger, index finger', will be analysed to show that their presence in PAcan probably be specifically attributed to the historical connection created between Brazil and Curaçao due to the forced migration of the Sephardic Jews and their servants.

6 John Holm, An Introduction to Pidgins and Creoles (Cambridge: Cambridge University Press, 2000) 78 .

7 Morris Goodman, The Portuguese Element in the American Creoles (Honolulu: University of Hawaii Press, 1987). 
Map 1 shows the main historical links that should be taken into consideration to understand the formation of PA.

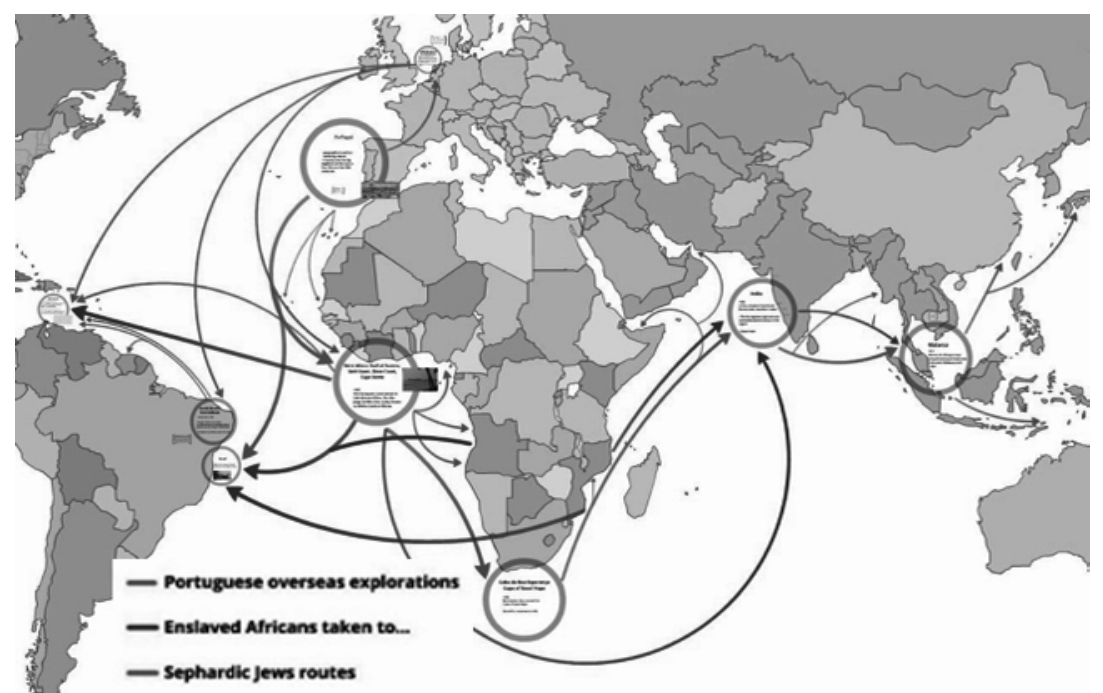

Map 1. Historical links to understand the formation of Papiamentu

Source: author's own map, prepared with free resources made available by Prezi (prezi.com)

Map 2 focusses specifically on the main routes taken by the Sephardic Jews and how they relate to their historical movement until they finally arrived in Curaçao. 


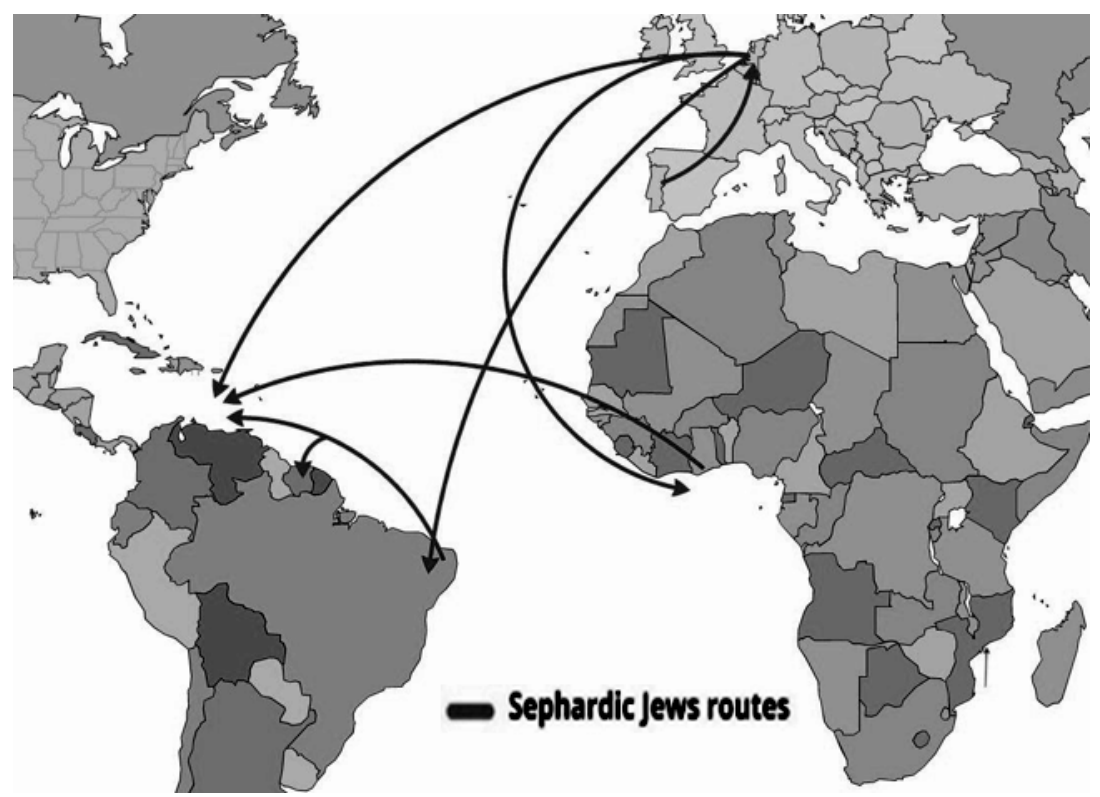

Map 2: The Sephardic Jews and Papiamentu

Source: author's own map, prepared with free resources made available by Prezi (prezi.com)

The route taken by the Sephardic Jews from Dutch Brazil via French Guiana and Suriname to Curaçao after they were expelled by the Portuguese provides the historical context to trace the possible origin of the three lexical elements analysed below.

\section{The Case of PA bacoba}

It is well known in the study of creole languages that open class words are not a good indicator of genetic, structural links between languages. However, the case of the PA noun bacoba $\sim$ bakoba ('banana') illustrates the links existing between Brazilian Portuguese and PA to some degree, even if that linguistic connection is usually not taken into account by some scholars. In PA, despite the fact that the majority of the words are of Ibero-Romance (around two-thirds) 
and Dutch (a bit less than one-third, about 30\%) origin, there are also words whose etymon is found in French, English and other languages.

While studying Africanisms that Papiamentu, Brazilian Portuguese and Uruguayan Spanish share, Johnen ${ }^{8}$ comes across the word bacoba, which Kramer classifies as of Dutch origin, claiming that it comes from the Dutch word bakove. ${ }^{9}$ But in a detailed analysis, Johnen ${ }^{10}$ successfully demonstrates that from the point of view of feasible phonetic alterations, the Dutch word bakove could never be incorporated into PA as bacoba, since final/-e/ schwa vowels in Dutch always develop into /-i/ in PA and never into /-a/. Therefore, if PA bacoba would have come from Dutch bakove, it should then rather have been realised in PA as bacobi, as in words like bonchi (from Dutch boontje, i.e., 'beans') and sunchi (from Dutch zoentje, i.e., 'kiss'). Apart from that, he also remarks that in Dutch there is no semantic difference between bacove and banaan, since both mean banana, whereas in PA there is the distinction between PA bacoba, which means banana, and PA banana, which in turn means plantain. ${ }^{11}$

Further on, Johnen shows that the word was incorporated into Dutch and into PA via Brazilian Portuguese, where it is realised as pacova pacoba, not from Dutch into PA as believed by Kramer. Many scholars believed this noun to be an Africanism, even without being able to mention any possible African linguistic source for it. ${ }^{12}$ Salles also refers to it under the entry for PT banana, when listing the different types of bananas there are in Brazil. He refers to Banana Pacova, Banana Pacovão and Banana Pacovi, classifying them all in

8 Thomas Johnen, Bakoba pa makaku: Sobre a problemática dos africanismos na lexicografia do Papiamentu (2014), manuscript.

9 Johannes Kramer, Kleines etymologisches Wörterbuch Papiamento-Deutsch Deutsch-Papiamento (Hamburg: Buske, 2013) 14.

10 Johnen (2014), 13.

11 Thomas Johnen, "Frederiks, Bernardus Th. J. (2009 [1859]): Woordenlijst der in der landstaal van Curaçao meest gebruikelijke woorden; alphabetisch neu geordnet mit dem heutigen Sprachstand verglichen und etymologisiert von Johannes Kramer, Hamburg: Buske (Kreolische Bibliothek; 22)," Lusorama 97-98 (2014): 254-265; Betty Ratzlaff, Papiamentu/Ingles dikshonario, English/ Papiamentu dictionary (Kralendijk: TWR Dictionary Foundation /Science Press, 1995) 21-22.

12 Johnen (2014), 13. 
the subtype of the pacovas. ${ }^{13}$ In fact, the Brazilian Portuguese word pacoba comes from one of the Brazilian native languages, namely Tupi, from the etymon pa 'koua. In his dictionary, Houaiss mentions the two variants for PT pacoba pacova as synonyms of banana, stating that the term appeared in PT before 1576 and observing the following in relation to its etymology: "tupi pa'kowa 'banana', com -w-, em posição intervocálica, consonantizando-se como labiodental $-v$ - ou, às vezes, como labial $-b-" .{ }^{14}$ (see entry for pacova in Dicionário Eletrônico Houaiss da Língua Portuguesa).

Furthermore, it is not just a coincidence that variants of Brazilian Portuguese pacova $\sim$ pacoba are present in creoles ${ }^{15}$ spoken along the route taken by the Sephardic Jews when they were expelled from Dutch Brazil and headed on into French Guiana, Suriname, Curaçao and other parts of the Caribbean. This causes Johnen to consider the following:

Es stellt sich nun natürlich die Frage, wie ein Tupi-Lexem, das kein Internationalismus geworden ist, ausgerechnet in FranzösischGuyana, Surinam und auf Curaçao als Lehnwort vertreten ist. Hier könnte ein Beleg für die viel diskutierte Verbindung zu Brasilien durch die (nach der Vertreibung der Niederländer aus Pernambuco) über Cayenne, Paramaribo nach Curaçao vor den Portugiesen geflohenen portugiesischen Juden bestehen. (...) Diese Beispiele mögen deutlich machen, dass es selbst bei dem Anteil des Papiamentuwortschatzes aus außereuropäischen Sprachen nicht reicht, das Spanische oder das Niederländische heranzuziehen. Der Vergleich mit dem Portugiesischen unter Einschluss des brasilianischen Portugiesisch ist zur Erforschung des Wortschatzes des Papiamentu unerlässlich. ${ }^{16}$

13 Vicente Salles, Vocabulário crioulo: contribuição do negro ao falar regional amazônico (Belém: Instituto de Artes do Pará, 2003) 66.

14 Antônio Houaiss. Dicionário Eletrônico Houaiss Da Língua Portuguesa. 3.0 (Rio de Janeiro: Objetiva, 2009). See entry for pacova. Own translation: "[From] Tupi pa'kowa 'banana', with the $-w$-, in intervocalic position, becoming a consonant operating as a labiodental $-v-$ or, sometimes, as a labial - $b$-."

15 Johnen (2014), 13.

16 Johnen (2009), 260-261. Own translation: "This now obviously fouces the question on how a Tupi lexeme, which did not turn into an internationalism, is present as loanword precisely in French Guiana, Suriname and Curaçao. This could be proof of the so often discussed connection to Brazil 
In Rossel's study on linguistic aspects of 'plantain' in Africa, she also refers to the origin of bakobe $\sim$ bacoba, observing that it is of Brazilian origin and it is present in the West of Africa. She believes that the term spread in Africa via a transmission from Fernando Pó, current Bioko, a Portuguese possession from 1474 to 1778. The transmission was possible due to the intense trade and human exchange and trafficking that existed between the two sides of the Atlantic Ocean:

On the western side of the continent we find bakobe 'banana' in Bubi on Fernando Po. From here this name spread, as -kube or -hube, to Noho and Puku, Batanga, Balong, Duala, Basaa and Mande in Cameroon. Further north along the West African coast, $K O B E$ names are used in a number of Kru languages in Ivory Coast. The name originates in South America, whence it must have been taken to West Africa by the Portuguese and / or Spanish. Pacoba is the name of Renealmia spp. (Zingiberaceae) in the languages of the Tupi Indians in Brazil and of Heliconia spp. (Strelitziaceae) in Guyana and Surinam. De Marees already mentioned this musa name in 1602 for Tupi (L'Honore Naber 1912: 167). Nowadays, bak(o)ba (in Papiamento) or bakove (in Sranan Tongo) is still a banana name in Surinam and Guyana (where the plantain is called bana, like in West Africa). ${ }^{17}$

Many other words in PA, especially Africanisms might have come via a Brazilian connection, but it is virtually impossible to prove it, given that they also exist in other Portuguese-based creoles, especially in Upper Guinea Portuguese creoles, so that they are more likely, but not necessarily, to have gone directly to Curaçao from Africa. The possibility of transmission via the established Brazilian connection

(after the expulsion of the Dutch from Pernambuco) through the Portuguese Jews that were escaping from the Portuguese via Cayenne and Paramaribo to Curaçao. (...) Those examples [he mentions others] may make clear that even in the share of the Papiamentu vocabulary from nonEuropean languages it does not suffice to draw on Spanish or Dutch. The comparison with Portuguese with the inclusion of Brazilian Portuguese is absolutely indispensable in the research on the Papiamentu vocabular."

17 Gerda Rossel, Taxonomic-Linguistic Study of Plantain in Africa (Leiden: Research School CNWS, 1998) 125. 
can also not be plainly discarded. In the case of the PA bacoba, however, the possibility of a connection via Africa is not impossible, but unlikely. A direct Brazilian connection via the Sephardic Jews seems to be more logical, given that other variants of the word bacoba can also be found along the way taken by the Sephardic Jews when heading to Curaçao.

Nevertheless, Johnen showed that phonetics speaks against a transmission via Dutch, because the term is a genuinely Brazilian Tupi noun first used as loanword in Brazilian Portuguese and then transmitted to other creole and non-creole languages, even leaving behind traceable footprints on its way from Brazil to the North of South America and into the Caribbean to make landfall in Curaçao and in PA.

\section{The Case of PA yaya}

As with bacoba, PA yaya also gives us good indications that we are dealing with a lexical item introduced into PA by the Sephardic Jews coming from Brazil. The feminine noun iaiá in Brazil means "tratamento dado às meninas e às moças, de largo uso no tempo da escravidão", ${ }^{18}$ as does "senhora, tratamento respeitoso dos escravos às patroas e suas filhas." 19 The term is clearly part of Afro-Brazilian culture and history; it was the respectful way that the enslavedAfricans and Afro-Brazilians had to approach their masters' wives. However, it is less frequently used today, being more restricted to certain linguistic contexts and regions. Its use has undergone a change in meaning; currently, it refers to 'woman, girl' and no longer to 'master, mistress'. Given that the masculine equivalent form is ioio, it is likely that the pair comes from the popular PT sinhá and sinhô, which in turn comes

18 Buarque de Holanda Ferreira, Aurélio. Novo Dicionário Eletrônico da Língua Portuguesa (Rio de Janeiro: Nova Fronteira, 2009). See term iaiá. Own translation: "way of addressing female children and young girls, videly used in the times of slavery."

19 Salles, 150. Own translation: "Madam, respectful way of slaves addressing their [female] masters and their daughters." 
from standard PT senhora 'madam' and senhor 'sir', respectively 20 ; therefore, its evolution is as follows: from PT senhora $>$ sinhora $>$

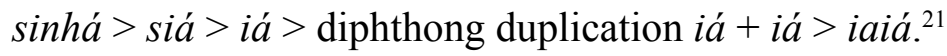

Specifically, the female term iaia is probably a result of lexical syncretism or convergence, given that the Yoruba and Hausa term iya means 'mother'. The second meaning of the term would also have come about by means of the emphatic repetition of iya +iya, resulting in iaiá. Afro-Brazilian religions refer to their mãe-de-santo, literally the 'mother of the saints', the priestess of Umbanda, Candomblé and Quimbanda, as Ialorixá (from Yoruba iyá + oló + orisá, 'mother + owner + deity, divinity'), or to the 'orisha of the winds and tempests' as Iansã (from Yoruba iyá + san, 'mother + thunderbolt'). The latter two examples show that iaiá $\sim i a$ with the meaning of 'mother', rather than just of 'lady, girl, madam', is also present in Brazilian PT vocabulary. Kikongo, one of the Bantu languages that also influenced Brazilian PT, has yaya, 'mother'. ${ }^{22}$ Yeda Pessoa de Castro refers to iaiá as a term of kwa/bantu origin, explaining that it is an archaic term used to approach a young woman respectfully, and is still observed in the speech of preto-velho (literally 'old black man'; in the Afro-Brazilian religion umbanda he represents the wise, kind and peaceful spirits of blacks that died as slaves). She also points to the Kimbundu and Yoruba roots yaaya and iya, respectively, and lists as equivalents the terms aia, nanã and sinhá. ${ }^{23}$ In any case, iaiá is always classified, not as a term of Portuguese or African origin, but specifically as of Brazilian origin by the main dictionaries of Portuguese, as can be verified in the Novo Aurélio, Houaiss, Porto Editora, Priberam, Caldas Aulete, Cândido de Figueiredo, amongst others.

20 Cf. Rojane Duarte, “A Origem e o Significado de Iaiá," Ciberdúvidas da Língua Portuguesa, 2007, 30 November 2017, <https://ciberduvidas.iscte-iul.pt/consultorio/ perguntas/a-origem-e-o-significado-de-iaia/20689>.

21 Houaiss, see entry iaiá.

22 Salles, 151.

23 Yeda Pessoa de Castro, Falares africanos na Bahia: Um vocabulário afro-brasileiro (Rio de Janeiro: Topbooks, 2001) 246. 
In PA, the term extrapolates that of 'female child', 'girl'or 'madam' and embeds exactly the meaning of 'mother', more specifically that of 'nanny, nursemaid' as noun in current PA(or in the slavery time that of 'servant-mother') or 'coddle, spoil, pamper' as verb. Interestingly, the productivity of the PA suffix - mentu generated yayamentu 'coddling, spoiling, pampering'. However, of greater interest for the purpose of this study is the noun yaya and the compound noun yaya di lechi 'one nursed by someone other than own mother'. ${ }^{24}$

Karner explains how the Sephardic Jews from Brazil also repeated in Curaçao the custom of choosing one of their mature female slaves to care for their offspring, a practice that even prevailed in the form of a nursemaid well after abolition. The author underlines the role of the yaya within a family and how African heritage, like Anansi stories, also became part of the childhood and the raising of Sephardic offspring in Curaçao. ${ }^{25}$ Rupert also highlights the role the yaya played in the learning and establishment of PA amongst the Sephardic Jews, and describes how she created bridges between them and the Afro-Curaçoans:

Communication among children of different social classes and ethnicities in Willemstad clearly spurred the development of Papiamentu. The crowded streets and alleyways of Punda and Otrobanda, with their dwellings, wharves, and commercial establishments in close proximity, encouraged children of different linguistic groups to play and try to speak together. Dutch visitors complained about the unintelligible language the children of Curaçao spoke in the eighteenth century. The role of children in developing and propagating creole languages is a well-established linguistic phenomenon. Linguists have noted the role of the black nanny or nursemaid in bridging the Sephardic and Afro-Curaçaoan communities, as she suckled the master's babies and brought them up alongside her own. The nanny,

24 For all terms above see Ratzlaff, 279.

25 Frances P. Karner, The Sephardics of Curacao: A Study of Socio-Cultural Patterns in Flux (Assen: Van Gorcum, 1969) 22-23. 
or yaya, as she was known in Curaçao, often was enslaved, but sometimes she was a free black or mulatto woman. Her close contact with white families, woman and children provided a setting that was rich with opportunities for cultural and linguistic exchange. ${ }^{26}$

As seen above, a yaya who was a wet nurse was called yaya di lechi in PA, usually known as ama-de-leite in PT. One of the synonyms of PT ama is aia, ${ }^{27}$, and aia is the term for a woman who is not a family member chosen to raise and educate the children, or a lady to keep company or be the chambermaid. The use of the term ama-de-leite, 'a surrogate mother that suckled' or nowadays 'a surrogate mother that suckles' (in case of the death of the mother or of some other impossibility of breastfeeding), is very common in PT, especially in texts referring to when this also was very common. Although rare, it is also possible to find the term aia-de-leite in PT. Apart from that, PT terms ama aia and iaiá seem to be lexically intertwined, since they all carry a sense of 'mother', showing that they eventually could be used one for another, since there are examples to attest it, despite the fact of aia and iaiá having different etymological origins.

The term aia can be traced back to the Gothic language, whereas iaiá is Afro-Brazilian. Therefore, it does not seem far-fetched for there to be a correspondence between the PT ama-de-leite aia-de-leite and the PA yaya di lechi, especially if taking into account that PT ama and aia are synonyms. Considering that the term iaiá is undoubtedly of Brazilian origin, as seen above, apart from the historic link created between Brazil and Curaçao by the Sephardic Jews, who had the custom of having a yaya to raise their children, all indications point towards a Brazilian, rather than Portuguese, West African or Spanish origin of the PA term yaya. This argument is further reinforced when the correspondence elucidated above for the compound yaya di lechi is also considered.

26 Linda M. Rupert, Creolization and Contraband: Curaçao in the Early Modern Atlantic World (Athens, Georgia: University of Georgia Press, 2012) 235.

27 Cf. the terms in Buarque de Hollanda Ferreira. 


\section{The Case of PA fulabola}

Amongst the isolated lexical items studied in this section to trace their etymological origin, none of them seems to have a more direct connection to Brazil than the PA word fulabola. It means 'forefinger, index finger' and presents three variants: fulabola in Aruba and fulabomba in Bonaire, ${ }^{28}$ and fulambeu in Curaçao. This term no longer a current word in PA, but it still can be found in PA children's rhymes. The question on how this term came into being in PA can only be answered, according to van Putte, when the Brazilian connection with Curaçao through the Sephardic Jews is taken into consideration. The term is part of a PA children's rhyme presented by him in the Curaçoan variant:

Dede pikiña

ku su bisiña

(...)

Mayor di todo,

Fulambeu

Piki ta su pieu ${ }^{29}$

Van Putte also mentions the Curaçoan poet Ellis Juliana, who resorts to fika un bola when referring to the index finger. The equivalent, very popular children's rhyme in Brazil is available in many children's books and easily found, since it is of public domain:

\begin{tabular}{|c|c|c|}
\hline $\begin{array}{l}\text { Portuguese } \\
\text { Dedo mindinho, } \\
\text { seu-vizinho, } \\
\text { pai de todos, } \\
\text { fura-bolo, } \\
\text { mata-piolho }\end{array}$ & $\begin{array}{l}\text { Possible variation } \\
\text { minguinho } \\
\text { maior de todos } \\
\text { fura-bolos } \\
\text { cata-piolho }\end{array}$ & $\begin{array}{l}\text { English } \\
\text { 'little finger' } \\
\text { lit. 'his neighbour', 'ring finger' } \\
\text { lit. 'father biggest of all', 'middle finger' } \\
\text { lit. 'cake pricker/piercer', 'index finger' } \\
\text { lit. 'lice killer picker', 'thumb' }\end{array}$ \\
\hline
\end{tabular}

28 Ratzlaff, 84.

29 Florimon Van Putte, "Dede Pikina, de Braziliaanse Connectie En de Yaya," Kristôf XII, 4 (2003): 34. 
Van Putte analyses a possible origin for the names given to the fingers in this rhyme and concludes that they can be of either Portuguese or Spanish origin, except for one of them. For him, it is precisely fulambeu that is the key to its origin: It is only found in PT. Nevertheless, since we are dealing here with an entire children's rhyme with an equivalent in Brazilian folklore, van Putte is certain that these isolated words for the different fingers were not pieced together in Curaçao. He rightly concludes that the whole rhyme was taken by the Sephardic Jews from Brazil to Curaçao and that "in het licht van het voorgaande is het duidelijk dat er een connectie is tussen dede pikiña en de folklore van Brazilië." ${ }^{30}$ Once in Curaçao, the rhyme would have found its way into PA amongst the Sephardic Jews and by means of the yaya, of the Sephardic families, who would have passed it on not only to the new generations of their masters' children, but also to their own children.

Dictionaries of Portuguese corroborate Van Putte's allegation, since they describe the PT equivalent term fura-bolo as a Brazilian regionalism, as for example, in the following entry: "Regionalismo: Brasil. 1 Uso: informal. O dedo indicador." ${ }^{31}$ Apart from that, Câmara Cascudo also mentions the term fura-bolo and the whole rhyme as part of Brazilian folklore in his dictionary, classifying it as a mnemonic commonly used in children's rhymes. ${ }^{32}$

More recently, further examples can be found in Aruba that attest to the use of these finger names. The Aruban poet, writer and performer Rosabelle Chuchi Illes uses some of them in a song called Camufla ('to disguise'), which was released in 2017 by her and Datapanik. In October 2017, the Biblioteca Nacional Aruba celebrated the 98 years of Jose Maria Dania who is considered its 'baluarte', which is a word that describes an experienced person that is a 'stronghold' in terms of culture, ideas and/or actions. During an interview conducted in the

30 Van Putte, 37.

31 Houaiss, see entry fura-bolo.

32 Luis da Câmara Cascudo, Dicionário do folclore brasileiro (Rio de Janeiro: Ediouro, 2003) 343. 
Biblioteca Nacional Aruba for a TV news program of Tele Aruba, Jose 'Joe' Maria Dania, who is sometimes just called Pai or Papai, 'Dad', mentioned and showed a picture with the typical Aruban Divi-Divi tree and a hand drawn with the following inscription on it: "E number cariño di kada dede. Dede pikinja, ku su bisiña, major de todo, fulan bola, mata karanja. Refreska bo mente ku number di cariño di kada dede. Djo Danja (Pai). ${ }^{\prime 3}$ During the interview, it is mentioned that Dania knows many old popular proverbs and rhymes like the one referring to the names of the 5 fingers. Therefore, PA fulabola $\sim$ fulabomba fulambeu $\sim$ fulan bola provides additional evidence of the linguistic connection between PA and Brazilian Portuguese.

\section{Final Remarks}

As mentioned at the beginning of this paper, it might be difficult to prove that some of the PA features present in the deeper layers of the language could be attributed specifically to an influence from Brazilian Portuguese or the Portuguese spoken by the Sephardic Jews. However, there definitively are direct links between PA and Brazilian Portuguese established by the Sephardic Jews and their servants, analysed above. The PA items bacoba, yaya and fulabola discussed here illustrate the linguistic connection between PA and Brazilian Portuguese, at least when it comes to the incorporation of lexical items, an absolutely feasible phenomenon, when the historic and linguistic bridges built by the Sephardic Jews and their servants between Brazil and the ABC Islands are considered.

33 Own translation: "The fond (from the childhood) name of each finger. [The names of the five fingers are provided in the sequence from the little finger to the thumb]. Refresh your mind with the fond name of each finger. Joe Danja (Father [one of his nicknames]).". This picture appeared along with a short interview with Joe Danja given to Mirto Lacle in the news program Telenoticias. Local News. Tele Aruba, 10 October 2017, starting at 32'07'. 12 October 2017. <http://www.telearuba. aw/2017/10/11/telenoticia-10-oct-2017/> or $<$ https://vimeo.com/237674647>. 
